\title{
Evaluation and Remaining Life Assessment of Separator and Demister in a Geothermal Power Generation Plant
}

\author{
Meilinda Nurbanasari and Abdurrachim
}

\begin{abstract}
Evaluation and remaining life assessment of separator and demister for $55 \mathrm{MW}$ geothermal power generation plant have been conducted. The equipment has been used for 27 years and has stopped operating due to the failure of steam turbine. Before it is operated back, the condition of separator and demister needs to be evaluated and their remaining life assessment has to be calculated to anticipate the future repair. The methods used for evaluation were UT phased array, thickness measurement, chemical composition, hardness test and deposit composition analysis. The remaining life assessment was calculated in correlation with thickness reduction. The results showed that the chemical composition and hardness of materials met the standard of SA $516 \mathrm{Gr} 70$. No evidence of internal defect was found in both equipment. The demister in all part is still in good condition and its remaining life was beyond 20 years. In separator, the reduction in thickness extremely occurred on top head and cone. The remaining life of top head separator was below 1.2 years and cone separator was not more than 4.7 years. Deposit analysis taken from demister gave evidence the presence of sulfur, silica, iron oxide, and sulfide iron.
\end{abstract}

Index Terms - Separator, demister, thinning rate, remaining life assessment.

\section{INTRODUCTION}

The condition and life assessment of engineering component must be paid great attention for safety and economic reasons [1], [2]. Although the engineering components are designed for long service life under continuous use, the premature failure may occur. Material degradation, corrosion, erosion, fatigue, operational and maintenance errors are common factor for the old engineering components [3]. On the other hand, many engineering components could be used beyond the recommended design life. Therefore, re-evaluation of old components is important to perform safely and well. Separator and demister are important components in geothermal power generation plant to provide a good quality steam for turbine. The separator has a function to split the geothermal fluid into two phases e.g.; vapor and liquid. The separator itself does not need any maintenance except there are corrosion and erosion of internal surface. The function of the demister is to remove all condensed liquid droplets of incoming steam as well as dust particle that can go together the steam. The demister is periodically cleaned to avoid

Manuscript received October 9, 2015; revised December 23, 2015

Meilinda Nurbanasari is with the Department of Mechanical Engineering, Institut Teknologi Nasional, Bandung, Indonesia Jl. PHH. Mustapha 23, Bandung, 40124, West Java, Indonesia (e-mail: meilinda@itenas.ac.id).

Abdurrachim is with the Department of Mechanical Engineering, Institute Technology of Bandung, Indonesia, Jl. Ganesha 10, Bandung 40132, West Java, Indonesia (e-mail: halimppy@yahoo.com). further accumulation of scale on the elements. In this study, the separator and demister are used for a $55 \mathrm{MW}$ geothermal generation power plant and have been operated for 27 years. The equipment had stopped operating due to steam turbine damage. The steam receiving station separator was designed and fabricated in accordance with ASME code section VII Division 1 [4]. Before they were operated back, non-destructive integrity inspections were conducted to seek chemical leaks, discontinuities, visible corrosion, material degradation and progress of thinning. The integrity inspection aims to ensure that both equipment will operate efficiently, safely and reliably. The assessment of remaining life was also calculated to predict the repair and the spare parts that need to be replaced in the future.

\section{INSPECTION METHOD}

The mechanical design of separator is cylindrical shell with a size of $1800 \mathrm{~mm}$ in diameter and $19 \mathrm{~mm}$ in height. The separator was designed for maximum working temperature of $205{ }^{\circ} \mathrm{C}$, maximum working pressure of $10.2 \mathrm{~kg} / \mathrm{cm} 2$ and corrosion allowance is $3 \mathrm{~mm}$. The demister has a diameter of $2200 \mathrm{~mm}$ and height of $5990 \mathrm{~mm}$. The non-destructive test (NDT) methods used to evaluate the condition of the equipment namely;

1) UT phased array (Olympus) was used to find internal defects

2) Wall thickness was measured using ultrasonic testing (Olympus EPOCH 4)

3) Bulk chemical composition of material separator and demister was determined using PMI - OES method (positive material identification - optical emission spectroscopy; Master Pro - Oxford instrument)

4) Chemical composition of deposit was analyzed using SEM EDS and conducted on JEOL 610-LA operated at $20 \mathrm{KV}$. XRD was also used to identify the compound of deposit and was conducted on Shimadzu XD-610 using Copper radiation with $0.05^{\circ}$ step size. The sample was scanned from $2 \theta=5$ up to $80^{\circ}$.

5) In-situ hardness test used Mitech MH 320 portable hardness tester with a 200 gram load. The average thickness was calculated from twelve measurements.

6) The remaining life assessment was calculated using the equations below [5]:

$$
\mathrm{RLP}=\frac{t_{\text {measured }}-t_{\text {min }}}{(f) L_{P}}
$$

where: RLP $=$ Remaining Life Prediction, $t_{\text {measured }}=$ measured thickness 
$t_{\min }=$ minimum allowed thickness and calculated using equation [6]:

$$
t_{\min }=\frac{P D_{i}-t_{\text {initial }}}{2(S E-P(1-Y))}=\frac{P D_{i}}{2 S E-1.2 P}
$$

$?=$ safety factor (in this study, ? =2, 15)

$L_{p}=$ thinning rate and calculated using equation [7]:

$$
L_{P}=\frac{t_{\text {measured }}-t_{\text {initial }}}{n}
$$

$t_{\text {initial }}=$ initial thickness, $\mathrm{n}=$ operating time $(=27$ years $)$

$P=$ working pressure, $\mathrm{Di}=$ inside diameter

$S=$ allowable stress $=\frac{\sigma_{y}}{f}=260[8] / 2,15=120,8 \mathrm{MPa}$

$E=$ Joint efficiency ( $E$ is equal to 0.85 based on manufacturer's data)

$Y=$ Material factor ( $Y$ is equal to 0.4 based on manufacturer's data)

Fig. 1 shows location for integrity inspection on demister and separator.

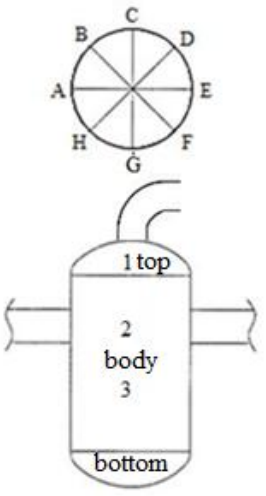

(a) demister

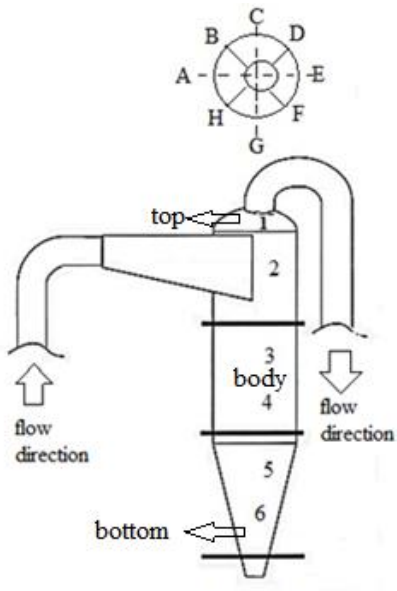

(b) separator
Fig. 1. Location for integrity inspection on (a) demister and (b) separator. For a description of numbers in the figure, see text.

In general, the inspected area was divided into three parts; top (number 1 on demister and separator), body (number 2 and 3 on demister, and number 2, 3, 4 on separator), and bottom (number 5 and 6 on separator). The area for internal defect inspection and thickness measurement is shown by number 1, 2, 3 on demister and 1, 2, 3, 4, 5, 6 on separator. The area for chemical composition determination was on the bottom of the equipment. The area for hardness test was number $1,2,3$ on demister and number 2, 3, 6 on separator.

\section{RESULTS AND DISCUSSIONS}

The measured chemical composition of demister was $0.21 \% \mathrm{C}, 0.65 \% \mathrm{Mn}, 0.22 \% \mathrm{Si}, 0.05 \% P$ (in wt $\%$ ) and separator was $0.19 \% \mathrm{C}, 1.06 \% \mathrm{Mn}, 0.17 \% \mathrm{Si}, 0.02 \% \mathrm{P}$ (in $\mathrm{wt} \%$ ). The average hardness value of demister and separator was $168.9 \pm 25.7 \mathrm{HB}$ and $142.42 \pm 9.3 \mathrm{HB}$, respectively. It can be concluded from the chemical composition and hardness data that the material of demister and separator met the standard of ASTM 516 Gr.70. The recapitulation of thickness measurement on demister is shown in Table I.

TABLE I: THE RECAPITULATION OF THICKNESS MEASUREMENT ON DEMISTER

\begin{tabular}{|c|c|c|c|c|c|c|c|c|c|c|}
\hline \multirow{2}{*}{$\begin{array}{c}\text { Location } / \\
\text { Area }\end{array}$} & \multicolumn{10}{|c|}{ Thickness $(\mathrm{mm})$} \\
\cline { 2 - 12 } & $\mathrm{A}$ & $\mathrm{B}$ & $\mathrm{C}$ & $\mathrm{D}$ & $\mathrm{E}$ & $\mathrm{F}$ & $\mathrm{G}$ & $\mathrm{H}$ & Min & Average \\
\hline \hline 1 & 20.97 & 21.00 & 20.92 & 21.45 & 20.53 & 21.45 & 21.33 & 21.56 & 20.53 & 21.15 \\
\hline 2 & 22.38 & 21.80 & 21.93 & 21.93 & 21.86 & 21.52 & 21.77 & 21.74 & 21.52 & 21.87 \\
\hline 3 & 22.83 & 21.83 & 22.41 & 21.93 & 22.82 & 22.14 & 21.20 & 22.72 & 21.20 & 22.24 \\
\hline
\end{tabular}

From the Table I, it can be seen that the average thickness on top head demister is $21.15 \mathrm{~mm}$ and on body demister is $21.87 \mathrm{~mm}$. The minimum thickness on top head and body demister is $20.53 \mathrm{~mm}$ (location $1 \mathrm{E}$ ) and $21.20 \mathrm{~mm}$ (location $3 \mathrm{G})$, respectively. The results show that in general, the wall thickness of demister decreased uniformly, which indicates that uniform corrosion had occurred at internal surface. Using equation (3) and based on technical specification of demister from manufacturer, the initial wall thickness of demister is 22 $\mathrm{mm}$, hence the thinning rate at top head demister is 0.05 mmpy and at body demister is $0.03 \mathrm{mmpy}$. From data in the Table II, it can be checked that some of the measured thickness data is higher than initial thickness that may be due to inhomogeneity walls thickness during manufacturing process. By considering the corrosion allowance is $3 \mathrm{~mm}$, and all measured thickness is above $19 \mathrm{~mm}$, therefore the demister is still in good working condition. The recapitulation of thickness measurement on separator is also presented in Table II.

\begin{tabular}{|c|c|c|c|c|c|c|c|c|c|c|}
\hline \multicolumn{11}{|c|}{ SEPARATOR } \\
\hline \multirow{2}{*}{$\begin{array}{c}\text { Location } \\
\text { / Area }\end{array}$} & \multicolumn{10}{|c|}{ Thickness (mm) } \\
\hline & A & B & C & D & $\mathrm{E}$ & F & G & $\mathrm{H}$ & Min & Average \\
\hline 1 & 11.79 & 11.81 & 11.91 & 11.75 & 11.73 & 11.69 & 11.98 & 11.81 & 11.69 & 11.81 \\
\hline 2 & 19.97 & 20.07 & 19.87 & 20.19 & 20.06 & 20.18 & 20.21 & 19.94 & 19.87 & 20.06 \\
\hline 3 & 20.00 & 21.00 & 19.53 & 20.99 & 20.11 & 20.73 & 20.22 & 20.39 & 19.53 & 20.37 \\
\hline 4 & 19.93 & 19.83 & 20.12 & 20.21 & 20.23 & 20.41 & 20.28 & 20.03 & 20.00 & 20.13 \\
\hline 5 & 11.95 & 11.98 & 12.36 & 11.97 & 12.27 & 12.24 & 12.03 & 12.03 & 11.95 & 12.10 \\
\hline 6 & 12.04 & 12.33 & 12.44 & 12.26 & 12.32 & 12.30 & 12.06 & 12.23 & 12.04 & 12.25 \\
\hline
\end{tabular}

TABLE II: THE RECAPITULATION OF THICKNESS MEASUREMENT ON

The data in Table II reveals that the minimum thickness on top head separator is $11.69 \mathrm{~mm}$ (location: $1 \mathrm{~F}$ ) and the minimum thickness on body separator is $19.53 \mathrm{~mm}$ (location: 3C). The lowest thickness occurred on bottom (cone) separator, which is $11.95 \mathrm{~mm}$ (location 5A). It must be noted that the top head separator has been repaired by jacketing process in 2009 due to leakage. The wall thickness of jacket is $15 \mathrm{~mm}$. Hence, the thinning rate on top head separator was calculated using the initial thickness of jacket $(15 \mathrm{~mm})$. The initial thickness of body separator and cone separator is 19 $\mathrm{mm}$ and $25 \mathrm{~mm}$, respectively. The initial thickness of body separator is lower than measured thickness. As occurred in the demister, it is probably due to inhomogeneity during manufacturing process. From the aforementioned thickness data, and the corrosion allowance for separator is $3 \mathrm{~mm}$, it can be concluded that the body separator is still safe to be used. However, great attention must be given on top head and cone separator as their wall thickness is extremely decreasing, which indicates that the corrosion rate of them was fast. The remaining life assessment was calculated using the equation (1) and the data is shown in Table III. 
TABLE III: REMAINING LIFE ASSESSMENT OF DEMISTER AND SEPARATOR

\begin{tabular}{|c|c|c|c|c|c|c|c|c|c|c|}
\hline \multirow[b]{2}{*}{ Equipment } & \multirow[b]{2}{*}{ Material } & \multirow[b]{2}{*}{ Area } & \multirow[b]{2}{*}{$\begin{array}{c}\text { Inside } \\
\text { Diameter } \\
(\mathrm{mm})\end{array}$} & \multirow[b]{2}{*}{$\begin{array}{c}\text { Initial } \\
\text { thickness } \\
(\mathrm{mm})\end{array}$} & \multirow[b]{2}{*}{$\begin{array}{l}\text { Working } \\
\text { pressure } \\
(\mathrm{MPa})\end{array}$} & \multirow[b]{2}{*}{$\begin{array}{c}\text { Allowable } \\
\text { stress } \\
(\mathrm{MPa})\end{array}$} & \multirow{2}{*}{$\begin{array}{c}\text { minimum } \\
\text { allowed } \\
\text { thickness } \\
(\mathrm{mm})\end{array}$} & \multicolumn{2}{|c|}{ Result } & \multirow{2}{*}{$\begin{array}{l}\text { Remaining } \\
\text { Life } \\
\text { Prediction } \\
\text { (year) }\end{array}$} \\
\hline & & & & & & & & $\begin{array}{c}\text { minimum } \\
\text { thickness } \\
(\mathrm{mm})\end{array}$ & $\begin{array}{l}\text { thinning } \\
\text { rate } \\
\text { (mmpy) }\end{array}$ & \\
\hline \multirow{3}{*}{ Separator } & \multirow{3}{*}{\begin{tabular}{|c|} 
SA $516-70$ \\
(ASTM \\
A516 \\
Gr.70)
\end{tabular}} & Top head & \multirow{2}{*}{2900} & \multirow{2}{*}{19} & \multirow{3}{*}{0.67} & \multirow{3}{*}{120.8} & \multirow{2}{*}{9.5} & 11.69 & 0.83 & $<1.2$ \\
\hline & & Body & & & & & & 19.53 & - & $>20$ \\
\hline & & Cone & 2175 & 25 & & & 7.1 & 11.95 & 0.48 & $<4.7$ \\
\hline \multirow{2}{*}{ Demister } & \multirow{2}{*}{$\begin{array}{c}\text { ASTM } \\
\text { A516 Gr.70 }\end{array}$} & Top head & \multirow{2}{*}{2200} & \multirow{2}{*}{22} & \multirow{2}{*}{0.67} & \multirow{2}{*}{120.8} & \multirow{2}{*}{7.2} & 20.53 & 0.05 & $>20$ \\
\hline & & Body & & & & & & 21.20 & 0.03 & $>20$ \\
\hline
\end{tabular}

From the data in Table III the remaining life assessment of top head and body demister is beyond 20 years and indicates in good condition. This condition is different from separator. In separator, as the decrease of measured thickness on body is not significant compared with initial thickness, it results the remaining life assessment of the separator can be beyond 20 years. Whereas, the remaining life assessment of top head and cone separator is less than 1.2 years and less than 4.7 years, respectively. Both parts must be given full consideration, especially on top head as the leakage may occur any time. Qualitative analysis of deposit SEM-EDS is shown in Fig. 2.

It can be seen that the deposit taken from demister contained of Sulphur, Aluminum and Silica. It is believed that both elements came from the geothermal as impurities and reacted with oxygen in the demister producing scale [9]. $\mathrm{X}$ ray diffraction was used to identify the compound in the deposit and the result is presented in Fig. 3.
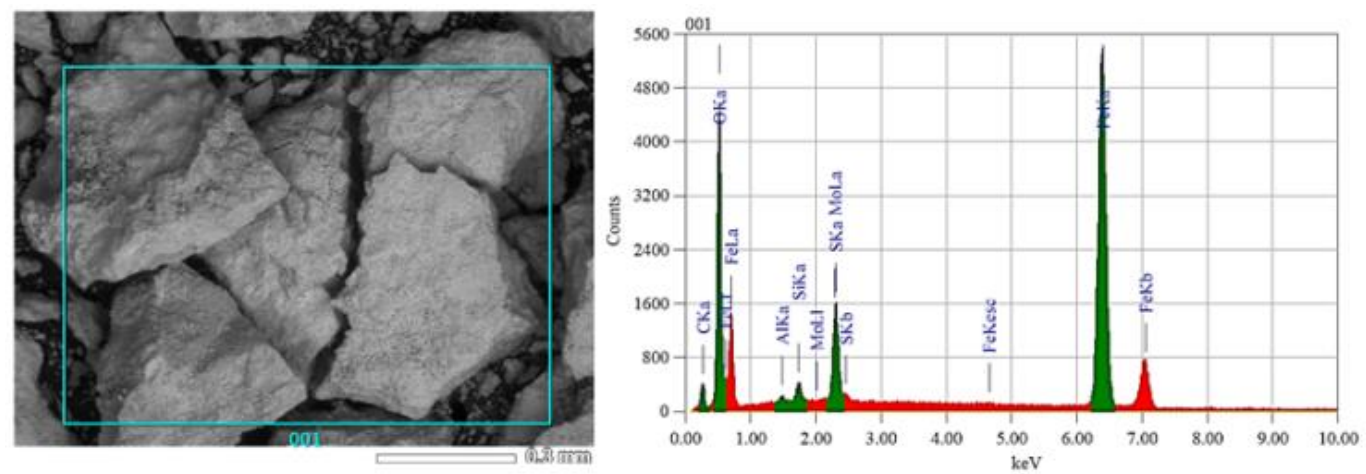

Fig. 2. SEM - EDS analysis of deposit from demister

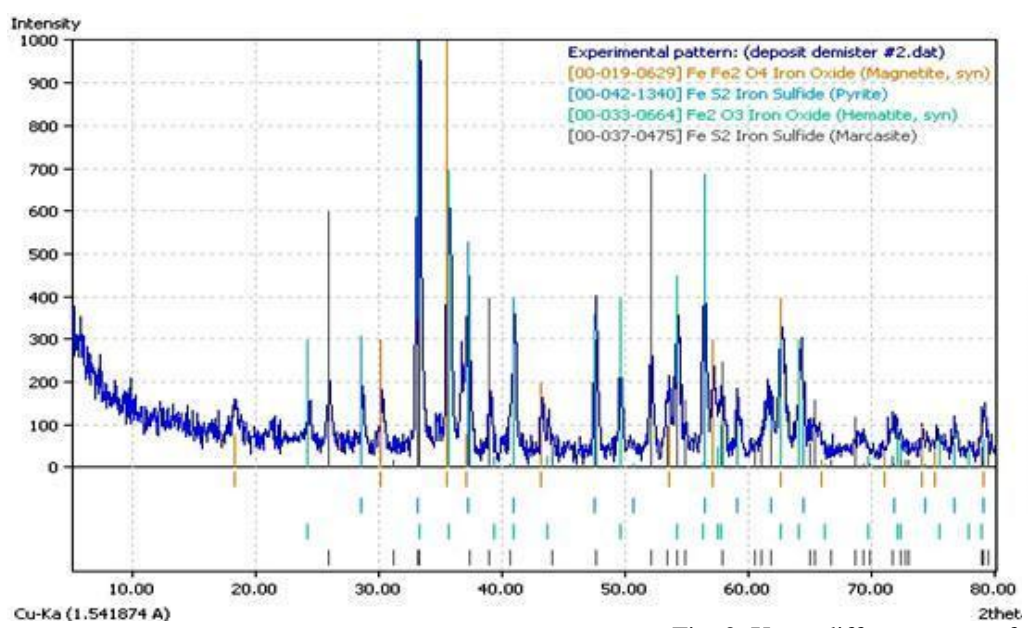

\begin{tabular}{|ll|c|}
\hline \multicolumn{2}{|c|}{ Compound } & $\begin{array}{c}\text { Powder } \\
\text { Diffraction File }\end{array}$ \\
\hline $\mathrm{Fe}_{3} \mathrm{O}_{4}$ & (Iron Oxide; Magnetite, syn) & $19-0629$ \\
\hline $\mathrm{FeS}_{2} \quad$ (Iron Sulfide; Pyrite) & $42-1340$ \\
\hline $\mathrm{Fe}_{2} \mathrm{O}_{3}$ & (Iron Oxide; Hematite, syn) & $33-0664$ \\
\hline $\mathrm{FeS}_{2} \quad$ (Iron Sulfide; Marcasite) & $37-0475$ \\
\hline \multicolumn{2}{|c|}{} \\
\hline
\end{tabular}

Fig. 3. X-ray diffractograms of deposit.

$\mathrm{X}$ rays diffraction detected some peaks in good agreement with $\mathrm{Fe}_{3} \mathrm{O}_{4}, \mathrm{FeS}_{2}, \mathrm{Fe}_{2} \mathrm{O}_{3}$ and $\mathrm{FeS}_{2}$. The presence of iron oxide on deposit gives strong evidence that corrosion had occurred inside the demister. No indication in the Fig. 3, the peak belongs to Silica compound. It seems that the scale containing Silica in the deposit is less than $5 \%$ that cannot be detected by XRD. The corrosion and formation of scale occurred simultaneously that cause reduction in thickness wall of the equipment.

\section{CONCLUSION}

Based on integrity inspection on demister and separator, the following conclusion can be made:

1) Demister is in good condition in all part and its remaining life assessment is beyond 20 years.

2) Deposit analysis shows the steam contained some impurities elements, such as $\mathrm{Si}, \mathrm{Al}, \mathrm{S}$.

3) Top head separator is in critical condition and its 
remaining life is less than 1,2 years.

4) The remaining life of cone separator is less than 4.7 years. The body separator is still in good condition and its remaining life is more than 20 years.

\section{REFERENCES}

[1] J. Zhao, S. Q. Han, H. B. Gao, and L. Wang, Remaining Life Assessment of a CRMOV Steel Using the Z-Parameter Method, Int. J. Press, Vessels Piping, vol. 81, pp. 757, 2004.

[2] C. J. Moss, P. Barrien, and A. Walcznski, Life Management of Refinery Furnace Tubing, Int. J. Press. Vessels Piping, vol. 77, pp. 105, 2000.

[3] R. N. Ghosh, Recent Trends in Sturctural Integrity Assessment, pp. $1-17,2001$

[4] ASME Code Section VII, Int boiler press vessel code, Three park avenue, $\mathrm{NY}, 2011$.

[5] F. Vicente, "Mechanical integrity assessment of a large horizontal NGL pressure vessel: Case study," Maintenance and Asset Management, vol. 25, pp. 36, 2010

[6] ASME Boiler Code Section I, Int. boiler Press, Vessel Code, Three park avenue, NY,2007.

[7] B. B. Jha, R. K. Galgali, and V. N. Misra, Futuristic Materials, 2004 Allied Publishers PVT, LTD, India, 2004.
[8] ASTM A516/A516M-10: Standard and Specification for Pressure Vessel Plates, Carbon Steel, for Moderate and Lower Temperature Service, ASTM International, West Conshohocken, PA, 2010.

[9] The International Association for the Properties of Water and Steam: Technical Guidance Document: Steam Purity for Turbine Operation, UK ,2013.

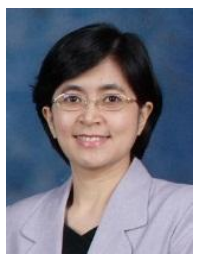

M. Nurbanasari is a senior lecture in the Mechanical Engineering Department, Institut Teknologi Nasional (ITENAS), Bandung, Indonesia. She received her Ph.D in material science and engineering from the University of Sheffield, UK in 2013. Her interests include heat treatment process, failure analysis and thermomechanical processing. She published a few papers in the international journal.

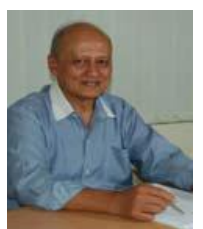

Abdurrachim is a senior lecture in the Faculty Engineering of Mechanical and Aerospace, Institut Teknologi Bandung (ITB), Bandung, Indonesia. He obtained his Ph.D from Science Physique Docteur aEtut France, Perpignan, France. His specializes in renewable energy, heat pipe and energy conversion, heat recovery and energy saving. 